\title{
Intermediate Detection in the Casiopeina-Cysteine Interaction Ending in the Disulfide Bond Formation and Copper Reduction
}

\author{
Lillian G. Ramírez-Palma ${ }^{1,2, \dagger}{ }^{\text {, Adrián Espinoza-Guillén }}{ }^{3,+}+\mathbb{C}$, Fabiola Nieto-Camacho ${ }^{3}$, Alexis E. López-Guerra ${ }^{3}$, \\ Virginia Gómez-Vidales ${ }^{1}$, Fernando Cortés-Guzmán ${ }^{1,2, *(D)}$ and Lena Ruiz-Azuara ${ }^{3, *(D)}$ \\ 1 Instituto de Química, Universidad Nacional Autónoma de México, Av. Universidad 3000, C. U., \\ México City 04510, Mexico; lila.gis.rp@gmail.com (L.G.R.-P.); gomvidal@unam.mx (V.G.-V.) \\ 2 Centro Conjunto de Investigación en Química Sustentable UAEMex-UNAM, Carretera Toluca-Atlacomulco \\ km 14.5, Toluca 50200, Mexico \\ 3 Facultad de Química, Universidad Nacional Autónoma de México, Av. Universidad 3000, C. U., \\ México City 04510, Mexico; adrianeg24@gmail.com (A.E.-G.); fabille.nc@gmail.com (F.N.-C.); \\ eduga_9@live.com.mx (A.E.L.-G.) \\ * Correspondence: fercor@unam.mx (F.C.-G.); lenar701@gmail.com (L.R.-A.) \\ + These authors contributed equally to this work.
}

Citation: Ramírez-Palma, L.G.; Espinoza-Guillén, A.; Nieto-Camacho, F.; López-Guerra, A.E.; GómezVidales, V.; Cortés-Guzmán, F.; Ruiz-Azuara, L. Intermediate Detection in the Casiopeina-Cysteine Interaction Ending in the Disulfide Bond Formation and Copper Reduction. Molecules 2021, 26, 5729. https: / / doi.org/10.3390/ molecules26195729

Academic Editors: Višnja Stepanić, Marta Kučerová-Chlupáčová and Helen Osborn

Received: 10 July 2021

Accepted: 14 September 2021

Published: 22 September 2021

Publisher's Note: MDPI stays neutral with regard to jurisdictional claims in published maps and institutional affiliations.

Copyright: (c) 2021 by the authors. Licensee MDPI, Basel, Switzerland. This article is an open access article distributed under the terms and conditions of the Creative Commons Attribution (CC BY) license (https:/ / creativecommons.org/licenses/by/ $4.0 /)$.

\begin{abstract}
A strategy to improve the cancer therapies involves agents that cause the depletion of the endogenous antioxidant glutathione (GSH), increasing its efflux out of cells and inducing apoptosis in tumoral cells due to the presence of reactive oxygen species. It has been shown that Casiopeina copper complexes caused a dramatic intracellular GSH drop, forming disulfide bonds and reducing $\mathrm{Cu}{ }^{\mathrm{II}}$ to $\mathrm{Cu}{ }^{\mathrm{I}}$. Herein, through the determination of the $\left[\mathrm{Cu}^{\mathrm{II}}\right]-\mathrm{SH}$ bond before reduction, we present evidence of the adduct between cysteine and one Casiopeina as an intermediate in the cystine formation and as a model to understand the anticancer activity of copper complexes. Evidence of such an intermediate has never been presented before.
\end{abstract}

Keywords: copper complexes; glutathione depletion; cysteine; Casiopeina; intermediate; copper reduction

\section{Introduction}

The study of the oxidation of endogenous thiolated compounds, such as glutathione (GSH) and cysteine (Cys), is essential to understand the oxidative stress within the cells [1]. Glutathione ( $\gamma$-L-glutamyl-L-cysteinyl-glycine, GSH) is a tripeptide that participates in redox processes into the cells, where the Cys residues of GSH are easily oxidized to disulfide (GSSG) $[2,3]$. It also participates in cancer cell protection against xenobiotics, ionizing radiations, and oxidative stress. Its oxidation favors the opening of the mitochondrial permeability transition pore complex, facilitating the release of death-related molecular signals [4,5]. A strategy to improve cancer therapies' efficacy should involve cytosolic and mitochondrial GSH depletion through an increase of GSH efflux out of cells [4]. Kachadourian and coworkers tested, in human lung cancer cells (H157 and A549), one copper complex of the Casiopeina ${ }^{\circledR}$ family, showing that it induced a dramatic drop in the intracellular levels of GSH (Figure 1A) [6]. Additionally, there are reports of GSH depletion produced by copper complexes on cervix HeLa and neuroblastoma CHP-212. GSSG/GSH and cystine/cysteine's redox potentials are very similar, -263 and $-220 \mathrm{mV}$ vs. normal hydrogen electrode (NHE) respectively [7,8], with glutathione being a slightly better reducing agent (Figure 1C). The oxidation by copper(II) ions of cysteine-containing peptides such as glutathione and cysteine has been studied to understand this biometal's role in oxidative stress processes [9-12]. The copper favors the oxidation of thiols [11,13], where $\mathrm{Cu}{ }^{\mathrm{II}}$ reacts with thiols to form $\left[\mathrm{Cu}^{\mathrm{II}}\right]$-thiol adducts depending on their molar ratio. The $\left[\mathrm{Cu}^{\mathrm{II}}\right]$-thiol complex is reduced to $\mathrm{Cu}^{\mathrm{I}}$, and in turn, thiols are oxidized to the corresponding radicals. The CasIII-ia ([Cu( $4,4^{\prime}$-dimethyl-2,2' -bipyridine) (acetylacetonate) $] \mathrm{NO}_{3}{ }^{*}\left(\mathrm{H}_{2} \mathrm{O}\right)_{2}$ ， 
Figure 1B) is a copper(II) complex from the Casiopeina family with a potential of $62 \mathrm{mV}$ vs. NHE [14], which could mediate the oxidation of biological thiols (Figure 1C). Recently, a paper [15] demonstrated the formation of $\mathrm{O}_{2} \cdot{ }^{-}$when bisdiimine copper(II) chelates were reduced by ascorbate. However, the pathway by which $\mathrm{Cu}^{\mathrm{II}}$ is reduced to $\mathrm{Cu}^{\mathrm{I}}$ has not yet been described; therefore, in this work, we present a strategy to understand this reduction process and determine the possible intermediate.

(A)

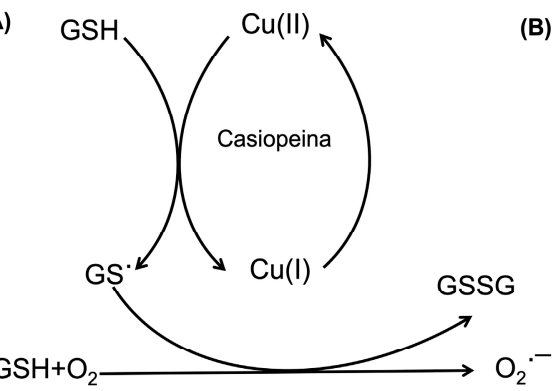

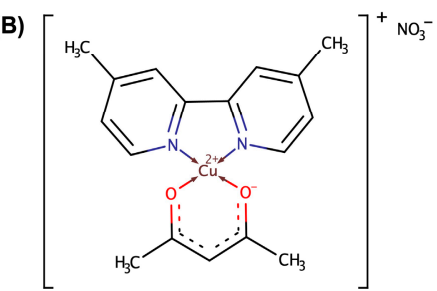

(C)

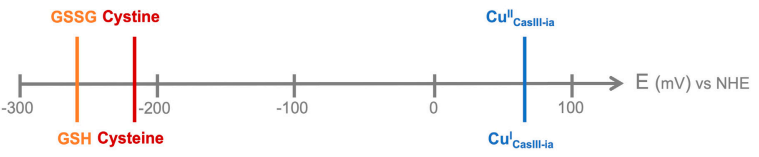

Figure 1. (A) The hypothesis of the interaction between the Casiopeina family and a thiolated redactor [6]. (B) CasIII-ia structure. (C) The redox potential of thiol-containing biomolecules and CasIII-ia.

These observations suggest the importance of copper complexes, such as the Casiopeinas, to oxidate thiol residues, inducing mitochondrial damage [6]. From the above considerations, in the present work, we study the specific interaction between cysteine and CasIII-ia to understand the pathway leading to a final reduction of the copper metal center and the disulfide bond formation. We focused on Cys, the reactive site of GSH, because it reacts slower than GSH in solution, and standard analytic techniques can detect its reactive intermediates. Additionally, we used mechanochemical methods to reduce the oxidation reaction rate. The family of Casiopeínas ${ }^{\circledR}[16]$ was designed considering three elements: copper(II) as a central metal and two mixed ligands with several substituents, providing to copper the possibility of producing cytotoxicity through different mechanisms of action [17]. Ligands modify the cationic copper's transport properties [18], the electronic properties of the central metal [19], and the molecular recognition of the complex [20]. The Casiopeina activity goes along with the cytotoxic effects, such as the generation of reactive oxygen species (ROS) [21,22], which can damage cellular components through oxidation and alter the oxidation-reduction balance cell or interfere with the mechanisms of cellular signaling related to the redox state [23]. There are reports about the antiproliferative and antineoplastic activities over murine and xenografted human tumors [24,25]. On the other hand, survival was evaluated in murine models: L1210 (leukemia), S180 (sarcoma), and B16 (melanoma) [26]. In non-tumor cells, the mean inhibitory concentration of this compound was 4.7, determined in lymphocytes, approximately 250 times higher than that observed in tumor lines, suggesting a selectivity towards tumoral cells [27]. Additionally, pharmacokinetic analyses performed with rat urine [28] and dog blood [29] samples have proved a high elimination rate of the Casiopeinas. All these results indicate an increase in the in vivo activity of the compound CasIII-ia, concerning the cisplatin activity as a positive control, evaluated in the same system. Our group has investigated the relationship between the features of the metal complex and their activity. A QSAR study showed that the half-wave potential and aromatic ring in the molecule are relevant for the compounds' action [14].

Other derived models can predict mixed chelate copper complexes' degree of activity based on the chemical correlation between structure, EPR, and electrochemical behavior, 
supported by DFT calculations [19]. We also developed a regression model to reproduce the antiproliferative activity involving the atomic delocalization and dipole moment changes within the ligands' C-N bonds [30]. These bonds are also determinant for the recognition site of copper complexes by the DNA backbone [20].

\section{Results and Discussion}

In solution, the endogenous reductant species, such as GSH, react very fast with Casiopeinas to be detected by standard analytical methods. For this reason, we decided to focus on the reactive site of GSH and Cys, and perform the reaction process in the solid state to observe the steps occurring in the Cys oxidation process. It has been reported that the Cys redox reaction barrier is smaller than the GSH one and also that the redox process is faster than any ligand exchange. In this way, Cys is an acceptable model of GSH for the process catalyzed by the CasIII-ia.

The CasIII-ia was prepared by the patent procedure [31-33]. To prove the inclusion of Cys in the copper coordination sphere and determine the features of the [C $\left.\mathrm{u}^{\mathrm{II}}\right]-\mathrm{Cys}$ interaction, we performed powder X-ray diffraction (PXRD), electronic spectra (UV-VisNIR), infrared spectroscopy (FTIR), electron paramagnetic resonance spectroscopy (EPR), and mass spectra-direct analysis in real-time (MS-DART) analyses. To understand the structural evolution of the $\left[\mathrm{Cu}^{\mathrm{II}}\right]-\mathrm{Cys}$ adduct, we carried out a DFT computational analysis for the cooper reduction process.

The reaction between equimolar solutions of Cys (colorless) and CasIII-ia (blue) showed color changes from brown/green to blue color (see the Movie S1 in the Supplementary Materials), and the same observations were reported by Seko et al. [34] and Ugone et al. [35]. EPR spectra of fresh mixtures of two CasIII-ia and Cys stoichiometric solutions were recorded at $77 \mathrm{~K}$. Figure 2 shows the copper electronic environment change of CasIII-ia when it interacts with Cys. Therefore, it is proposed that CasIII-ia generates a $\left[\mathrm{Cu}^{\mathrm{II}}\right]-\mathrm{Cys}$ adduct before its reduction. However, the reaction's rapid kinetics avoids studying the $\left[\mathrm{Cu}^{\mathrm{II}}\right]-C y s$ adduct in solution using this technique. Then, we opted to change the conditions to reduce the reaction rate with a mechanochemical solid-state approach. CasIII-ia and Cys were milled until a homogenous solid mixture was obtained, $\mathrm{EtOH}$ was added, and was mixed until dryness. During the mechanical process, it was possible to observe a color change, from Pantone 2139c to Pantone 289c (Figure 3), that can be associated with Cys' coordination to CasIII-ia. It was impossible to isolate and purify the reaction intermediates; therefore, we used several techniques to identify them within the reaction mixture.

(A)

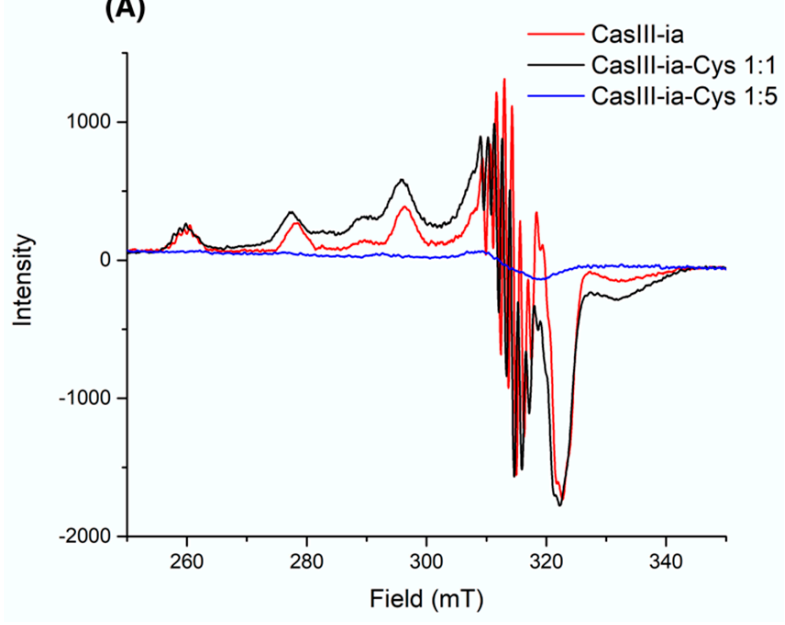

(B)

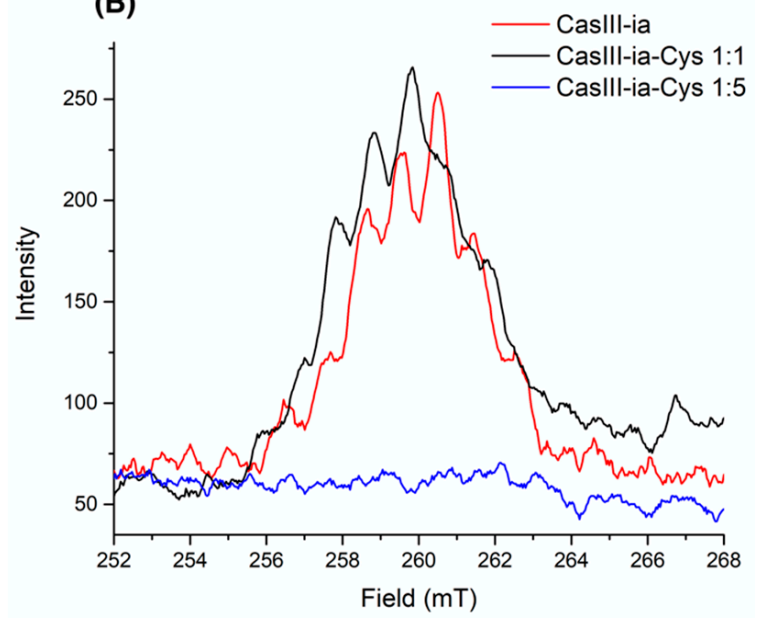

Figure 2. Experimental EPR spectra for CasIII-ia (1 mM) in red, CasIII-ia-Cys (1:1) in black, and CasIII-ia-Cys (1:5) in blue, in $\mathrm{MeOH} / \mathrm{H}_{2} \mathrm{O}$ (1:1) frozen solution at $77 \mathrm{~K}$. (A) From 250 to $350 \mathrm{mT}$, and (B) from 252 to $268 \mathrm{mT}$. 


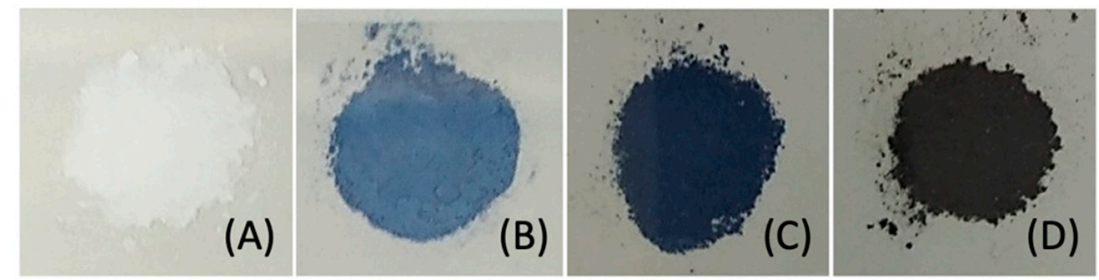

Figure 3. Reactant and intermediates of the mechanochemical solid-state reaction process: (A) cysteine (white), (B) CasIII-ia (Pantone 2139c), (C) intermediate 1 (Pantone 289c), and (D) intermediate 2 (Pantone 532c).

First, we analyzed the powder X-Ray diffraction patterns of the reactants and the reaction mixture. The crystal square pyramid structure of CasIII-ia has been reported in a previous description (CCDC 1440021). Supplementary Figure S1 shows the diffraction pattern of the reaction mixture and the two reactants. It is possible to observe that the crystalline arrangement is conserved. Some remnant signals can be associated with the Cys and the CasIII-ia; however, some signals are no longer present, such as the 7.9 intense signals in $2 \theta$. On the other hand, new signals are presented, such as 11.24, 12.12, 17.18, $25.94,32.58,33.02,37.92$, and 38.58 (see Supplementary Materials for details). These peaks confirm a new species that still have copper(II) as a metal center.

The second evidence of the presence of a new copper(II) complex is the UV-Vis spectrum of the reaction mixture, as shown in Figure 4. The reaction mixture spectrum resembles that for CasIII-ia-Cys, with maxima at 395 and $598 \mathrm{~nm}$. The latter can be associated with the electronic transitions of an elongated $\mathrm{D}_{4 \mathrm{~h}}$ octahedral structure. The simulated spectra show that the signals of two possible CasIII-ia-Cys adduct arrangements, octahedral (axial Cys) and square planar pyramid (equatorial Cys), are very close to the experimental ones, 626 and $663 \mathrm{~nm}$, respectively. The deconvolution of the two observed signals agrees with three theoretical excited states of octahedral and square planar pyramid geometries. These signals are mainly related to the transition to SOMO or LUMO molecular orbitals (for octahedral geometry: SOMO-20 $\rightarrow$ SOMO, SOMO-16 $\rightarrow$ SOMO, and SOMO-16 $\rightarrow$ LUMO; for square planar pyramid: SOMO-18 $\rightarrow$ SOMO, SOMO-18 $\rightarrow$ LUMO, and SOMO-15 $\rightarrow$ LUMO). Details are provided in the Supplementary Materials.
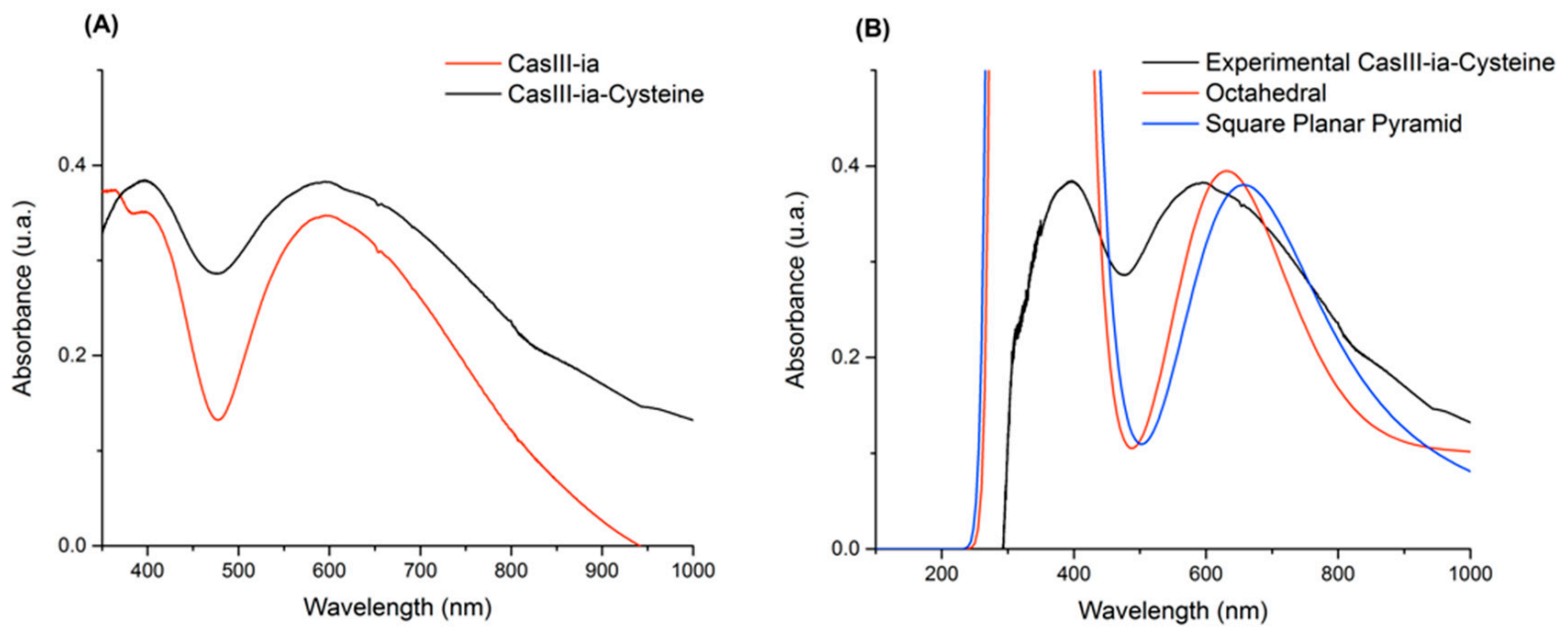

Figure 4. (A) UV-Vis spectra for CasIII-ia (red) and the reaction between CasIII-ia and cysteine (black). (B) UV-Vis spectra comparison between experimental reaction (black) and calculated geometries for the CasIII-ia-Cysteine system: octahedral (red) and square planar pyramid (blue).

The third evidence of the interaction between CasIII-ia and Cys is the EPR data. Figure 5 shows the experimental spectra and fitting models of CasIII-ia (A) and CasIII-iaCys (B). Table 1 presents experimental and computational values for the $\mathrm{g}$ and $\mathrm{A}$ tensors 
of the spectra in Figure 5. We compared the observed spectra with DFT simulations of octahedral and square planar pyramid structures. CasIII-ia shows an axial symmetry spectrum associated with a square planar pyramid geometry. The reaction product is a 1:1 CasIII-ia/CasIII-ia-Cys mixture in the solid state. The linear combination of the axial and isotropic EPR profiles of CasIII-ia and CasIII-ia-Cys reproduce the experimental spectrum. The axial symmetry can be associated with geometry with a pseudo-Janh-Teller effect, where a Cys occupies the axial position of CasIII-ia. The difference between the experimental and theoretical $g$ values ranges from 0.004 to 0.10 , and for A values, from 25 to $98 \mathrm{MHz}$. These differences agree with that obtained in other reports [36,37]. For the CasIII-ia-Cys, we compared the experimental data with two different geometries: octahedral and square planar pyramid. The difference between the experimental and theoretical data is 0.004 and 0.030 for $g_{\text {iso }}$, respectively. The $A_{\text {iso }}$ value differences are 56 and $25 \mathrm{MHz}$, respectively. The best fit for $\mathrm{g}_{\text {iso }}$ corresponds to octahedral geometry, while for $A_{\text {iso }}$ it is given by the square planar pyramid.
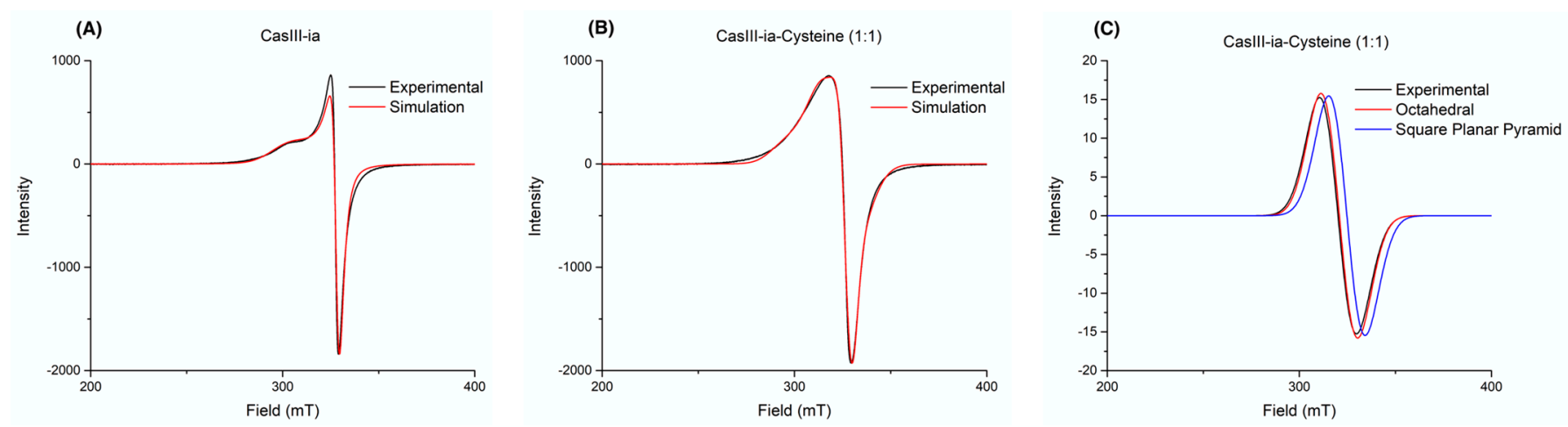

Figure 5. EPR spectra in the solid-state for (A) CasIII-ia and (B) CasIII-ia with cysteine reaction, and (C) comparison between experimental reaction and calculated geometries for the CasIII-ia-Cysteine system.

Table 1. Experimental and computational values for the $\mathrm{g}$ tensor and the A tensor (in $\mathrm{MHz}$ ) parameters of spectra A and B in Figure 5.

\begin{tabular}{|c|c|c|c|}
\hline \multicolumn{4}{|c|}{ CasIII-ia (A) } \\
\hline & \multicolumn{2}{|c|}{ Experimental } & Computational \\
\hline$g_{x x}=g_{y y}$ & \multicolumn{2}{|c|}{2.0767} & 2.0466 \\
\hline $\mathrm{g}_{\mathrm{zz}}$ & \multicolumn{2}{|c|}{2.2517} & 2.1458 \\
\hline $\mathrm{A}_{\mathrm{xx}}=\mathrm{A}_{\mathrm{yy}}$ & \multicolumn{2}{|c|}{7.47} & 105.26 \\
\hline $\mathrm{A}_{\mathrm{zz}}$ & \multicolumn{2}{|c|}{117.4} & -185.99 \\
\hline \multicolumn{4}{|c|}{ CasIII-ia-Cysteine 1:1 (B) } \\
\hline & Experimental & Octahedral & Square Planar Pyramid \\
\hline$g_{x x}=g_{y y}=g_{z z}$ & 2.10557 & 2.1010 & 2.0755 \\
\hline$A_{x x}=A_{y y}=A_{z z}$ & 48.797 & 104.57 & 23.85 \\
\hline
\end{tabular}

The fourth evidence of the Cu-S interaction is the I.R. signals presented in the Supplementary Materials. Since cysteine is a molecule of biological interest, its solid-state vibrational spectra have been extensively studied, considering the polymorphisms that it can show [38] and the I.R. modifications with different protonation modes [39]. The Cys I.R. signals S-H $\left(1063 \mathrm{~cm}^{-1}\right)$, C-S $\left(692 \mathrm{~cm}^{-1}\right)$, and C-N $\left(291 \mathrm{~cm}^{-1}\right)$ [38], agreeing with theoretical frequencies $\left(1056.73,669.99\right.$, and $278 \mathrm{~cm}^{-1}$, respectively), yield the most significant changes when interacting with the copper complex. In the case of CasIII-ia, the $\mathrm{Cu}-\mathrm{O}$ and $\mathrm{C}-\mathrm{N}$ bonds' I.R. signals appear at 596 and $294 \mathrm{~cm}^{-1}$ (603.88 and $279.73 \mathrm{~cm}^{-1}$ theoretical values), respectively. The 1:1 solid reaction mixture, with drops of $\mathrm{EtOH}$, produces an adduct which presents I.R. signal variations as evidence of the CasIII-ia-Cys interaction (Figure 6). Based 
on computational information (179 and $194 \mathrm{~cm}^{-1}$ for octahedral and SPP theoretical values, respectively), we can assign the frequency at $187 \mathrm{~cm}^{-1}$ to the $\mathrm{Cu}-\mathrm{S}$ interaction between CasIII-ia and Cys. It is possible to note signals associated with the metal-ligand interaction within CasIII-ia, such as $\mathrm{Cu}-\mathrm{O}\left(594 \mathrm{~cm}^{-1}\right)$ and $\mathrm{Cu}-\mathrm{N}\left(289 \mathrm{~cm}^{-1}\right) . \mathrm{Cu}-\mathrm{N}$ weakened after Cys coordination from 294 to $289 \mathrm{~cm}^{-1}$. The weakening of the C-S bond is shown by reducing the frequency from 692 to $685 \mathrm{~cm}^{-1}$. One can observe a small S-H at $1063 \mathrm{~cm}^{-1}$ as evidence of unreacted Cys.

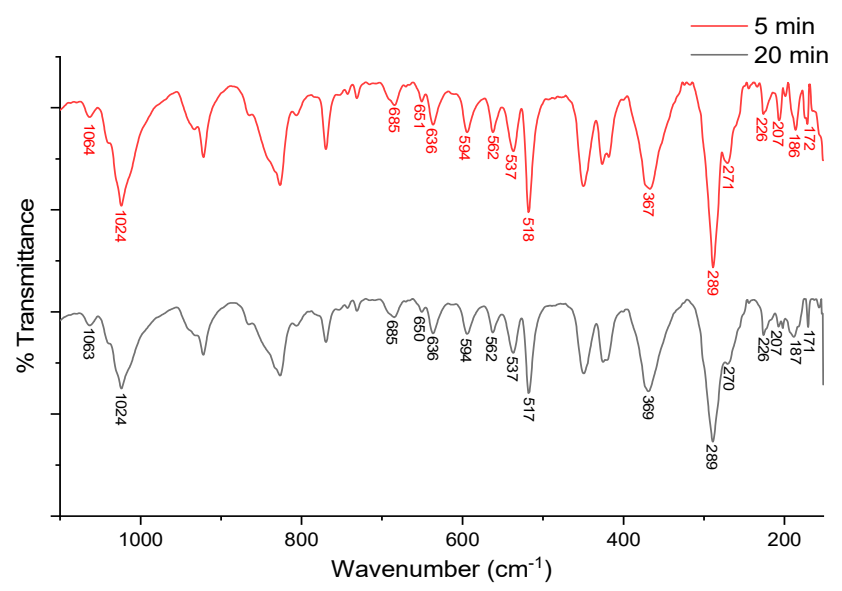

Figure 6. ATR-FTIR spectrum of CasIII-ia-Cys (1:1) mixture at 5 (red) and 20 (black) minutes.

After $\mathrm{NaOH}$ was added in an equimolar amount, $\mathrm{S}-\mathrm{H}$ frequency, at $1063 \mathrm{~cm}^{-1}$, disappeared, but the $\mathrm{C}-\mathrm{S}$ and $\mathrm{Cu}-\mathrm{O}$ vibrations remain. We confirmed that $\mathrm{Cu}-\mathrm{S}$ interaction is associated with the $187 \mathrm{~cm}^{-1}$ frequency. These signals correlate with those exhibited by octahedral theoretical geometry. Details are provided in the Supplementary Materials.

Our last evidence is from the direct analysis in real-time mass spectrometry (DARTMS). Under positive ionization of the DART technique, it has been reported that the amino-acid presents protonation, radical, and adduct formation [40]. In the Cys case, it is possible to observe [Cys $+\mathrm{H}]^{+}=122 \mathrm{~m} / \mathrm{Z}$ and $[2 \mathrm{Cys}+\mathrm{H}+\mathrm{H}]=243 \mathrm{~m} / \mathrm{Z}$. The mechanochemical solid-state mixture was analyzed using DART-MS, whose spectrum is presented in Figure 7 . It is possible to observe the signal associated with dimethylbipyridine $(\mathrm{m} / \mathrm{Z}=185.1), \mathrm{Cu}$ (acetylacetonate $)_{2}(\mathrm{~m} / \mathrm{Z}=262)$, and CasIII-ia $(\mathrm{m} / \mathrm{Z}=346)$. At $200{ }^{\circ} \mathrm{C}$, we found a signal of $\mathrm{m} / \mathrm{Z}=423$ corresponding to the CasIII-ia-Cys adduct, with a loss of carboxylic group. It has been reported that $\mathrm{Cys}$ loses $\mathrm{CO}$ in situations where the sulfur atom is involved in a bond or a strong interaction. The fragmentation pattern of Cys by DART-MS and cystine by TANDEM-MS both present the [Cistina- $\mathrm{H}_{2} \mathrm{O}-\mathrm{CO}+\mathrm{H}$ ] ion with $\mathrm{m} / \mathrm{Z}=195$ when the CO loss can be observed [41,42]. The presence of the signals at 346 and 348 for CasIII-ia, at 262 and 264 for $\mathrm{Cu}$ (acetylacetonate) ${ }_{2}$, and at 422.99 and 424.98 for the adduct agree with the isotopic distribution for ${ }^{63} \mathrm{Cu}$ and ${ }^{65} \mathrm{Cu}$ observed in a copper(II) species. The abundance of each peak can be related to the stability of the analyzed species [43]. In this way, the adduct is an unstable species compared with the CasIII-ia.

To understand the pathway leading to a final reduction of the copper metal center, we calculated the structures and their dynamics. The two possible molecular arrangements of the CasIII-ia-Cys adduct are the octahedral and the square planar pyramid (Figure 8). In the former, the sulfur atom occupies an axial coordination position at $2.82 \AA \mathrm{Cu}-\mathrm{S}$ distance. The latter presents the sulfur atom located in an equatorial position, at $2.37 \AA \mathrm{Cu}-\mathrm{S}$ distance. The square planar pyramid is $4.9 \mathrm{kcal} / \mathrm{mol}$ more stable than octahedral geometry. 

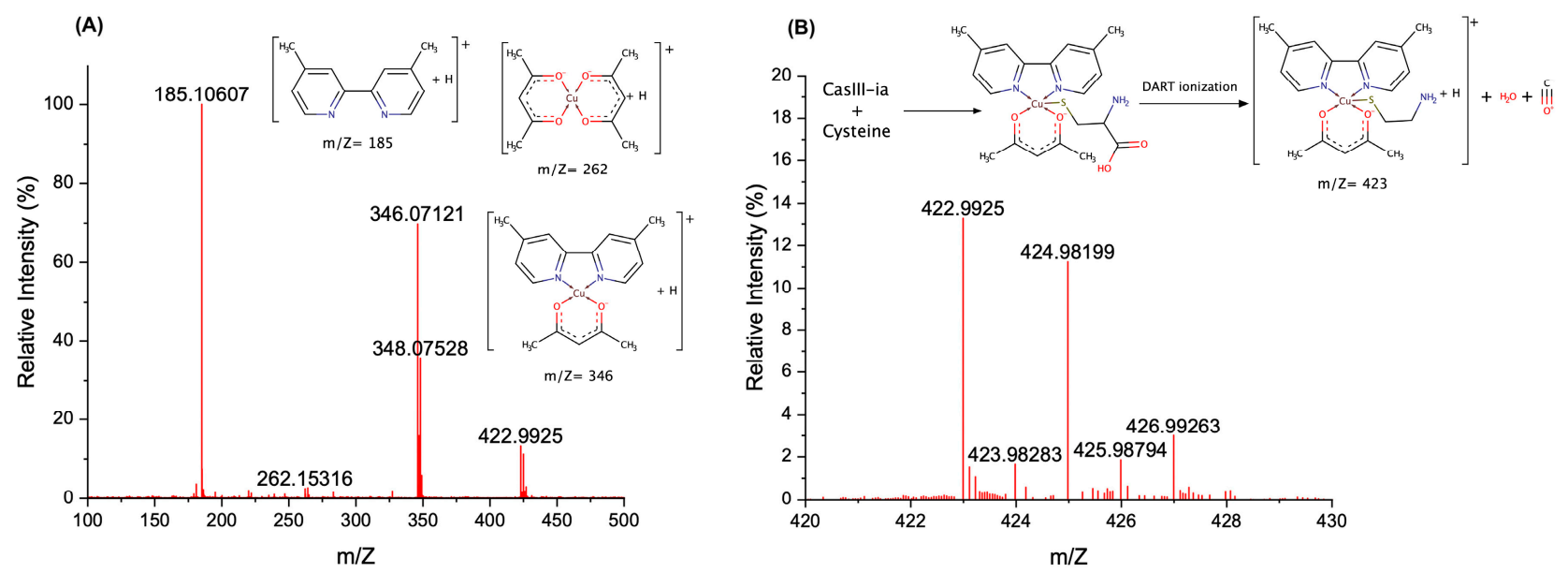

Figure 7. DART spectra of the mechanochemical solid-state mixture CasIII-ia-Cys at $200{ }^{\circ}$ C. (A) From 100 to $500 \mathrm{~m} / \mathrm{Z}$, and (B) from 420 to $430 \mathrm{~m} / \mathrm{Z}$.

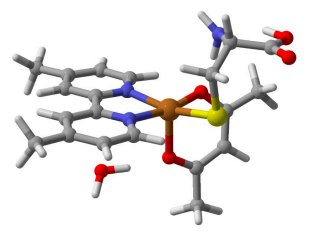

Square Planar Pyramid: $2.37 \AA$ $-4.9 \mathrm{kcal} / \mathrm{mol}$

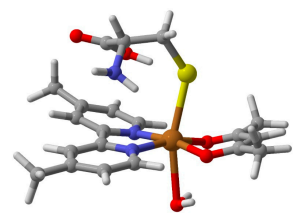

Octahedral: $2.82 \AA$ $0 \mathrm{kcal} / \mathrm{mol}$

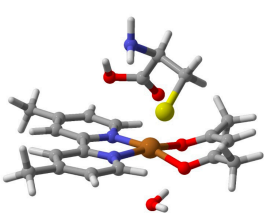

Before electron transfer: $3.9 \AA$ $-8.3 \mathrm{kcal} / \mathrm{mol}$
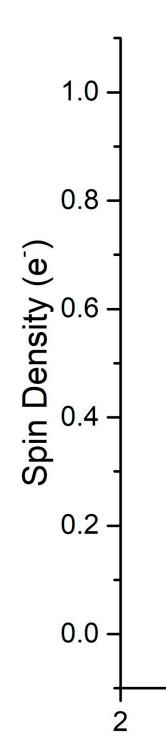

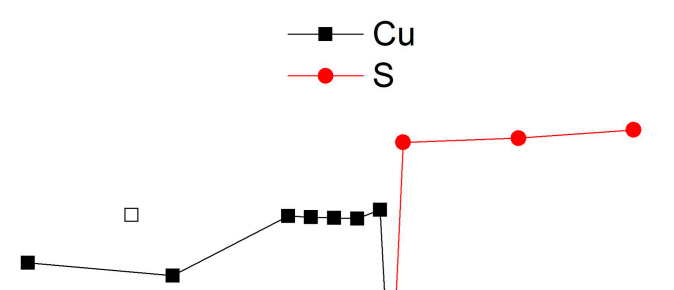

I

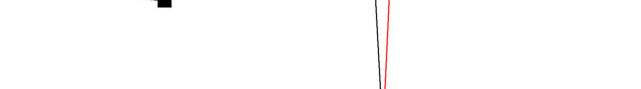

Figure 8. From square planar pyramid $\mathrm{Cu}^{\mathrm{II}}$ complex to tetrahedral $\mathrm{Cu}^{\mathrm{I}}$ complex, electron transfer path. Spin density values for copper atom in black and for sulfur atom in red.

The reductive process's reaction path begins from the Cys coordination to CasIII-ia in the square planar pyramid geometry, and it is presented in Figure 8, along with the atomic spin population. From the initial $2.37 \AA$, the $\mathrm{Cu}-\mathrm{S}$ distance increases until $3.9 \AA$, where the electron is transferred from sulfur to the copper atom. It is possible to observe a spin population change from 0.78 to $0.001 \mathrm{e}^{-}$in the copper atom, which is transferred to the sulfur atom, which shows an increase from 0.00 to $0.94 \mathrm{e}^{-}$. In this process, the copper valence shell changes, and then the geometry of the complex becomes tetrahedral. Our group has previously reported the spin change effect on the metal valence shell and thus on the complex structure $[44,45]$. From this point, the thiyl radical is free to participate in the following reaction to form the disulfide bond. Details are provided in the Supplementary Materials. 


\section{Materials and Methods}

\subsection{Chemicals}

All reagents: acetylacetone (acacH) (Sigma-Aldrich, St. Louis, $\mathrm{MO}, \mathrm{USA}), \mathrm{Cu}\left(\mathrm{NO}_{3}\right)_{2}$. $2.5 \mathrm{H}_{2} \mathrm{O}$ (Sigma Aldrich, St. Louis, MO, USA), and 4,4'-dimethyl-2,2'-bipyridine (dmbpy) (Sigma Aldrich, St. Louis, MO, USA), as the organic solvents, were used without further purification. L-cysteine (Cys) (Sigma Aldrich, St. Louis, MO, USA) was also used without further purification. The elemental analysis of the white crystalline powder for $\mathrm{C}_{3} \mathrm{H}_{7} \mathrm{O}_{2} \mathrm{~S}$ was \%C 29.82 (29.73), \%H 5.92(5.82), \%N 11.70 (11.56), \%S 26.97 (26.46) ((\#) calculated values). The far FTIR-ATR spectrum of a deep white powder of $\mathrm{Cys}$ showed characteristic bands at $1614 \mathrm{~cm}^{-1} \mathrm{CO}_{2}, 1063 \mathrm{~cm}^{-1} \mathrm{~S}-\mathrm{H}, 692 \mathrm{~cm}^{-1} \mathrm{C}-\mathrm{S}$, and $637 \mathrm{~cm}^{-1} \mathrm{CH}-\mathrm{CO}_{2}$.

\subsection{CasIII-ia Synthesis}

$\left[\mathrm{Cu}\left(4,4^{\prime}\right.\right.$-dimethyl-2,2'-bipyridine)(acetylacetonate) $\mathrm{NO}_{3}{ }^{*}\left(\mathrm{H}_{2} \mathrm{O}\right)_{2}$ (CasIII-ia) CAS [22393033-4], the copper(II) complex, was prepared following the reported patent [31-33]. The complex was isolated on $\mathrm{MeOH} / \mathrm{H}_{2} \mathrm{O}$ solution, and a blue crystalline powder was obtained. The elemental analysis of the blue powder for $\mathrm{CuC}_{17} \mathrm{H}_{19} \mathrm{~N}_{3} \mathrm{O}_{5}{ }^{*}\left(\mathrm{H}_{2} \mathrm{O}\right)_{2}$ was $\% \mathrm{C} 44.26$ (45.89), $\% \mathrm{H} 4.79(5.21)$, and \%N 9.45 (9.44) ((\#) calculated values). The far FTIR-ATR spectrum of a deep blue powder of CasIII-ia showed characteristic bands at $1616 \mathrm{~cm}^{-1} \mathrm{C}=\mathrm{O}$ (acac), $1373 \mathrm{~cm}^{-1} \mathrm{~N}-\mathrm{O}$ (nitrate), $596 \mathrm{~cm}^{-1} \mathrm{Cu}-\mathrm{O}$, and $294 \mathrm{~cm}^{-1} \mathrm{Cu}-\mathrm{N}$.

\subsection{Solid-State Reaction}

CasIII-ia (30 mg, $0.0674 \mathrm{mmol})$ and cysteine $(8.17 \mathrm{mg}, 0.0674 \mathrm{mmol})$ were milled until a homogenous solid was obtained. $\mathrm{EtOH}(400 \mu \mathrm{L})$ was added and mixed until dryness.

\subsection{Measurements}

Powder X-ray diffraction (PXRD) data were collected under ambient conditions on a Rigaku ULTIMA IV diffractometer operated at $160 \mathrm{~W}(40 \mathrm{kV}, 40 \mathrm{~mA})$ for $\mathrm{Cu} \mathrm{K} \alpha 1$ $(\lambda=1.5406 \AA)$.

Electron paramagnetic resonance spectroscopy (EPR) measurements were carried out in a JEOL JES-TE300 spectrometer operated at X-Band mode at a microwave frequency of $9.4 \mathrm{GHz}$ and center field of $300 \mathrm{mT}$. Solid-state measurements were performed at room temperature, where the samples were placed in a quartz cell. The acquisition and manipulation of spectra were performed using the ES-IPRIT/TE program. The $g$ and hyperfine tensors were determined by fitting the powder spectra using the EasySpin [46] simulation package (Version 5.2.28, easyspin.org, (accessed on 6 May 2020)) for MATLAB R2019b.

The solid-state electronic spectra (UV-Vis-NIR) for the samples were measured over the range $40,000-5000 \mathrm{~cm}^{-1}$ by the diffuse reflectance method on a Cary-5000 Varian spectrophotometer at room temperature.

The near-FTIR attenuated total reflectance (ATR) spectra were obtained over the range $4000-250 \mathrm{~cm}^{-1}$ on a Thermo Fisher Scientific Nicolet IS-50 spectrophotometer. The samples were examined as solid. The middle-FTIR spectra were obtained over the range $4000-400 \mathrm{~cm}^{-1}$ on a Nicolet spectrophotometer Nicolet AVATAR 320. The samples were analyzed as $\mathrm{KBr}$ disk.

The MS-DART spectra were acquired with a JEOL AccuTOF JMS-T100LC spectrometer. The samples were examined as solid. The values of the signals are expressed in mass/charge units $(\mathrm{m} / \mathrm{Z})$, followed by the relative intensity with reference to a $100 \%$ base peak.

The elemental analysis (EA) was carried out using The PerkinElmer ${ }^{\circledR} 2400$ Series II CHNS/O Elemental Analyzer.

\subsection{Computational Details}

All structures were fully optimized at the DFT level in gas phase, with the m05-2x functional and the LanL2DZ basis set, as implemented in Gaussian 09 software [47]. Then, we performed frequency calculations to verify the equilibrium states and to obtain infrared spectra. We used the TD-DFT CAM-B3LYP/SDD theoretical level for the UV-Vis spectra, 
with the SMD solvation model, with water as the solvent. For the electron transfer studies, we used the Quantum Theory of Atoms In Molecules [48], using the set of molecular orbitals of each molecule to compute the atomic properties of the electron density with the AIMAll software [49]. EPR parameters and $g$ and A tensors of the optimized structures were calculated with ORCA software [50], using the B3LYP functional and the def2-SVP basis set.

The initial complex presented a square planar geometry with a water molecule in one axial site, as in the reported crystallographic geometry [51]. Then, a cysteine molecule was linked to the complex by the vacant axial site, yielding an octahedral geometry. A base in the environment removes the -SH proton, expelling the water molecule from the opposite side. We detected the electron transfer by the complex change to a tetrahedral geometry, which is the geometry preferred by a copper atom with a $1+$ oxidation state.

\section{Conclusions}

A strategy to improve cancer therapies' efficacy should involve cytosolic and mitochondrial GSH depletion through an increase of GSH efflux out of cells. There are reports of GSH depletion produced by copper complexes of the Casiopeina family. In this work, we presented experimental evidence of the formation of an adduct between cysteine and a Casiopeina complex. This adduct shows equilibrium between octahedral and square planar pyramid structures. From this equilibrium, it is possible to identify an electron transfer path when the $\mathrm{Cu}-\mathrm{S}$ distance increases to $3.9 \AA$, which produces a thiyl radical and a reduced tetrahedral copper(I) complex. The proposed mechanism is presented in Figure 9 .
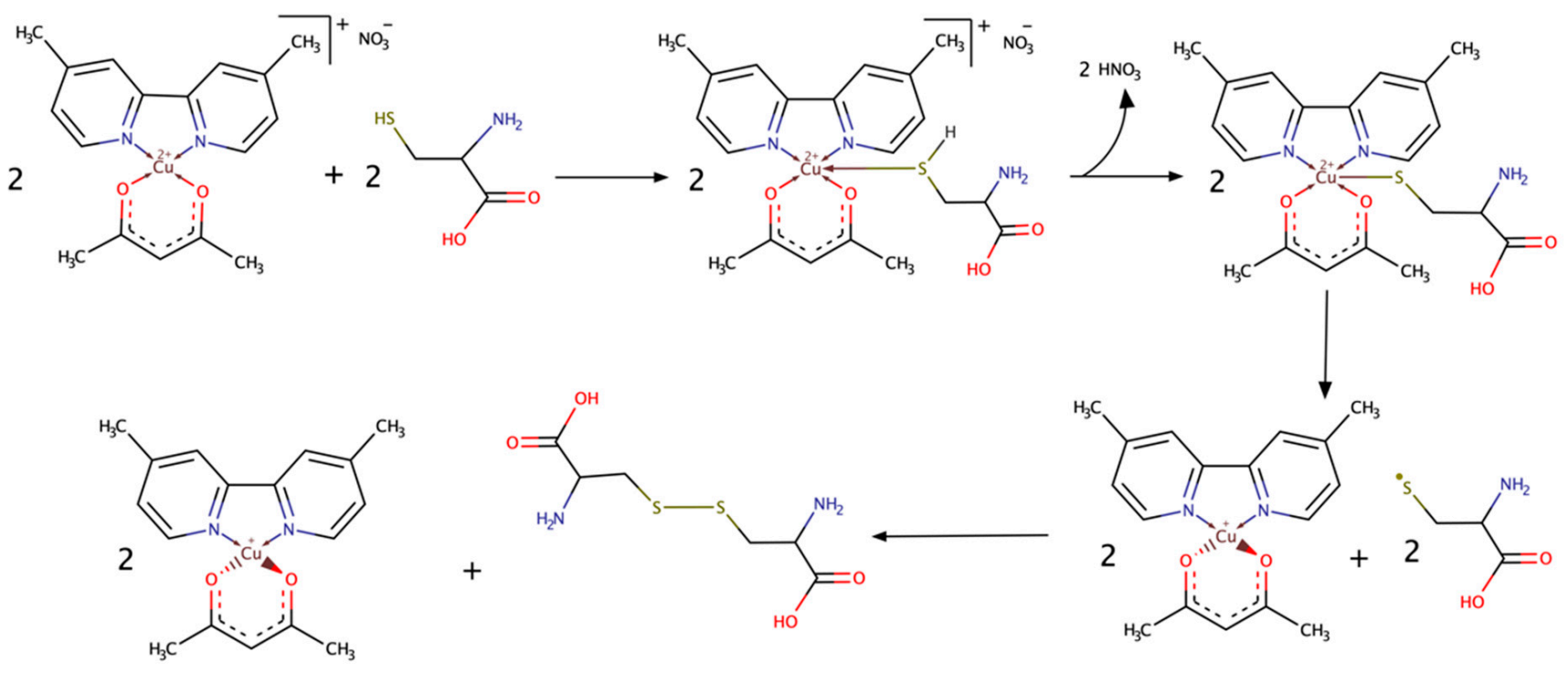

Figure 9. Proposed mechanism for the interaction between CasIII-ia and cysteine.

Supplementary Materials: The following are available online, Video S1: Reaction in solution. Experimental Details: Figure S1: Powder X-ray diffraction, Table S1: Powder X-ray diffraction (PXRD) data, Table S2: Experimental EPR parameters, Figure S2: Details of the CasIII-ia:Cysteine (1:1) EPR simulation, Figure S3: Deconvolved UV-Vis spectra, Table S3: Comparison between deconvolved and computational values for UV-Vis transitions, Figures S4-S7: Details of ATR-FTIR spectra, Table S4: Main absorption infrared signals, Figures S8 and S9: MS-DART spectra for reactants, computational calculations: optimized geometries, Figures S10-S14: UV-Vis spectra, Figures S15-S17: Infrared spectra, Tables S5-S8: Infrared signals, Table S9: Calculated EPR parameters, Figure S18: Spin density changes, Table S10: Spin density values for $\mathrm{Cu}$ and S atoms, Figure S19: Spin density changes in Cu-S bond distance scan, Figure S20: Geometries in the $\mathrm{Cu}-\mathrm{S}$ bond distance scan, Figures S21 and S22: Copper Atomic graphs. 
Author Contributions: L.G.R.-P.: methodology, formal analysis, investigation, data curation, writingoriginal draft preparation, and writing-review and editing; A.E.-G.: methodology, formal analysis, investigation, data curation, writing - original draft preparation, and writing - review and editing; F.N.-C.: investigation; A.E.L.-G.: investigation; V.G.-V.: methodology; F.C.-G.: conceptualization, writing - original draft preparation, writing - review and editing, supervision, project administration, and funding acquisition; L.R.-A.: conceptualization, writing - original draft preparation, writingreview and editing, supervision, project administration, and funding acquisition. All authors have read and agreed to the published version of the manuscript.

Funding: This research was funded by UNAM (PAPIIT-IN212520, PAPIIT IN218013, and PAIP 50009047) and CONACYT (CB179119). F.N.-C. and A.E.L.-G. thank SNI (grant "Ayudantes de Investigador Nacional SNI III/Emérito") and L.G.R.-P. thanks CONACyT for the fellowship (308338). We also thank DGTIC-UNAM (LANCAD-UNAM-DGTIC-194) for supercomputer time and USAII-UNAM for elemental analysis.

Institutional Review Board Statement: Not applicable.

Informed Consent Statement: Not applicable.

Data Availability Statement: Data is contained within the article and Supplementary Material.

Acknowledgments: The authors thank I.A. Ibarra-Alvarado and E. Sánchez-González for PXRD determinations, M. C. García for MS-DART determinations, and R. Patiño Maya for I.R. determinations.

Conflicts of Interest: The authors declare no conflict of interest.

Sample Availability: Samples of the compounds are available from the authors.

\section{References}

1. Baba, S.P.; Bhatnagar, A. Role of thiols in oxidative stress. Curr. Opin. Toxicol. 2018, 7, 133-139. [CrossRef] [PubMed]

2. Aquilano, K.; Baldelli, S.; Ciriolo, M.R. Glutathione: New roles in redox signaling for an old antioxidant. Front. Pharmacol. 2014, 5, 196. [CrossRef] [PubMed]

3. Ulrich, K.; Jakob, U. The role of thiols in antioxidant systems. Free Radic. Biol. Med. 2019, 140, 14-27. [CrossRef]

4. Ortega, A.L.; Mena, S.; Estrela, J.M. Glutathione in Cancer Cell Death. Cancers 2011, 3, 1285-1310. [CrossRef] [PubMed]

5. Bansal, A.; Simon, M.C. Glutathione metabolism in cancer progression and treatment resistance. J. Cell Biol. 2018, 217, 2291-2298. [CrossRef] [PubMed]

6. Kachadourian, R.; Brechbuhl, H.M.; Ruiz-Azuara, L.; Gracia-Mora, I.; Day, B.J. Casiopeína IIgly-induced oxidative stress and mitochondrial dysfunction in human lung cancer A549 and H157 cells. Toxicology 2010, 268, 176-183. [CrossRef] [PubMed]

7. Millis, K.K.; Weaver, K.H.; Rabenstein, D.L. Oxidation/Reduction Potential of Glutathione. J. Org. Chem. 1993, 58, 4144-4146. [CrossRef]

8. Jocelyn, P.C. The Standard Redox Potential of Cysteine-Cystine from the Thiol-Disulphide Exchange Reaction with Glutathione and Lipoic Acid. Eur. J. Biochem. 1967, 2, 327-331. [CrossRef]

9. Ngamchuea, K.; Batchelor-McAuley, C.; Compton, R. The Copper(II)-Catalyzed Oxidation of Glutathione. Chem.-Eur. J. 2016, 22, 15937-15944. [CrossRef]

10. Kachur, A.V.; Koch, C.J.; Biaglow, J.E. Mechanism of copper-catalyzed autoxidation of cysteine. Free Radic. Res. 1999, 31, 23-34. [CrossRef]

11. Prudent, M.; Girault, H.H. The role of copper in cysteine oxidation: Study of intra- and inter-molecular reactions in mass spectrometry. Metallomics 2009, 1, 157-165. [CrossRef]

12. Carrasco-Pozo, C.; Aliaga, M.E.; Olea-Azar, C.; Speisky, H. Double edge redox-implications for the interaction between endogenous thiols and copper ions: In vitro studies. Bioorg. Med. Chem. 2008, 16, 9795-9803. [CrossRef] [PubMed]

13. Smith, R.C.; Reed, V.D.; Hill, W.E. Oxidation Of Thiols By Copper(II). Phosphorus. Sulfur. Silicon Relat. Elem. 1994, 90, 147-154. [CrossRef]

14. Bravo-Gómez, M.E.; García-Ramos, J.C.; Gracia-Mora, I.; Ruiz-Azuara, L. Antiproliferative activity and QSAR study of copper(II) mixed chelate $\left[\mathrm{Cu}(\mathrm{N}-\mathrm{N})(\right.$ acetylacetonato) $] \mathrm{NO} 3$ and $\left[\mathrm{Cu}(\mathrm{N}-\mathrm{N})(\right.$ glycinato) $] \mathrm{NO} 3$ complexes, (Casiopeínas $\left.{ }^{\circledR}\right)$. J. Inorg. Biochem. 2009, 103, 299-309. [CrossRef]

15. Santoro, A.; Calvo, J.S.; Peris-Díaz, M.D.; Krężel, A.; Meloni, G.; Faller, P. The Glutathione/Metallothionein System Challenges the Design of Efficient O2-Activating Copper Complexes. Angew. Chem.-Int. Ed. 2020, 59, 7830-7835. [CrossRef] [PubMed]

16. Ruiz-Azuara, L. MéxicoTítulo de Marca: Casiopeína. Reg. 407543 SECOFI, 1992.

17. Arredondo, M.; Núñez, M.T. Iron and copper metabolism. Mol. Asp. Med. 2005, 26, 313-327. [CrossRef]

18. Bravo-Gómez, M.E.; Dávila-Manzanilla, S.; Flood-Garibay, J.; Muciño-Hermández, M.Á.; Mendoza, Á.; García-Ramos, J.C.; Moreno-Esparza, R.; Ruiz-Azuara, L. Secondary Ligand Effects on the Cytotoxicity of Several Casiopeína's Group II Compounds. J. Mex. Chem. Soc. 2012, 56, 85-92. [CrossRef] 
19. García-Ramos, J.C.; Galindo-Murillo, R.; Tovar-Tovar, A.; Alonso-Saenz, A.L.; Gómez-Vidales, V.; Flores-Álamo, M.; Ortiz-Frade, L.; Cortes-Guzmán, F.; Moreno-Esparza, R.; Campero, A.; et al. The $\pi$-Back-Bonding Modulation and Its Impact in the Electronic Properties of CuII Antineoplastic Compounds: An Experimental and Theoretical Study. Chem._Eur. J. 2014, 20, 13730-13741. [CrossRef]

20. Galindo-Murillo, R.; Ruiz-Azuara, L.; Moreno-Esparza, R.; Cortés-Guzmán, F. Molecular recognition between DNA and a copper-based anticancer complex. Phys. Chem. Chem. Phys. 2012, 14, 15539-15546. [CrossRef]

21. Klaunig, J.E.; Kamendulis, L.M. The Role of Oxidative Stress in Carcinogenesis. Annu. Rev. Pharmacol. Toxicol. 2004, 44, $239-267$. [CrossRef]

22. Gaetke, L.M.; Chow, C.K. Copper toxicity, oxidative stress, and antioxidant nutrients. Toxicology 2003, 189, 147-163. [CrossRef]

23. Huang, R.; Wallqvist, A.; Covell, D.G. Anticancer metal compounds in NCI's tumor-screening database: Putative mode of action. Biochem. Pharmacol. 2005, 69, 1009-1039. [CrossRef]

24. Carvallo-Chaigneau, F.; Trejo-Solís, C.; Gómez-Ruiz, C.; Rodríguez-Aguilera, E.; Macías-Rosales, L.; Cortés-Barberena, E.; CedilloPeláez, C.; Gracia-Mora, I.; Ruiz-Azuara, L.; Madrid-Marina, V.; et al. Casiopeina III-ia induces apoptosis in HCT-15 cells in vitro through caspase-dependent mechanisms and has antitumor effect in vivo. BioMetals 2008, 21, 17-28. [CrossRef] [PubMed]

25. Bravo-Gómez, M.E.; Hernández de la Paz, A.L.; Gracia-Mora, I. Antineoplastic evaluation of two mixed chelate copper complexes (Casiopeínas ${ }^{\circledR}$ ) in HCT-15 xenograft model. J. Mex. Chem. Soc. 2013, 57, 205-211. [CrossRef]

26. Ruiz-Azuara, L.; Bravo-Gómez, M.E. Copper Compounds in Cancer Chemotherapy. Curr. Med. Chem. 2010, 17, 3606-3615. [CrossRef]

27. García-Ramos, J.C.; Gutiérrez, A.G.; Vázquez-Aguirre, A.; Toledano-Magaña, Y.; Alonso-Sáenz, A.L.; Gómez-Vidales, V.; FloresAlamo, M.; Mejía, C.; Ruiz-Azuara, L. The mitochondrial apoptotic pathway is induced by Cu(II) antineoplastic compounds (Casiopeínas ${ }^{\circledR}$ ) in SK-N-SH neuroblastoma cells after short exposure times. BioMetals 2017, 30, 43-58. [CrossRef]

28. Vértiz, G.; García-Ortuño, L.E.; Bernal, J.P.; Bravo-Gómez, M.E.; Lounejeva, E.; Huerta, A.; Ruiz-Azuara, L. Pharmacokinetics and hematotoxicity of a novel copper-based anticancer agent: Casiopeina III-Ea, after a single intravenous dose in rats. Fundam. Clin. Pharmacol. 2014, 28, 78-87. [CrossRef]

29. Cañas-Alonso, R.C.; Fuentes-Noriega, I.; Ruiz-Azuara, L. Pharmacokinetics of Casiopeína IIgly in beagle dog: A copper based compound with antineoplastic activity. J. Bioanal. Biomed. 2010, 2, 28-34. [CrossRef]

30. Ramírez-Palma, L.G.; García-Jacas, C.R.; García-Ramos, J.C.; Almada-Monter, R.; Galindo-Murillo, R.; Cortés-Guzmán, F. Pharmacophoric sites of anticancer metal complexes located using quantum topological atomic descriptors. J. Mol. Struct. 2020, 1204, 127480. [CrossRef]

31. Ruiz-Azuara, L. Process to Obtain New Mixed Copper Aminoacidate from Methylate Phenanthroline Complexes to Be Used as Anticancerigenic Agents. U.S. Patent 5,576,326, 19 November 1996.

32. Ruiz-Azuara, L. Procedimiento para la Obtención de Complejos Metálicos como Agentes Anticancerígenos. Tipo II. Patente de in-Vención SECOFI 18801, 1994.

33. Ruiz-Azuara, L. Composición Parental de Casiopeína y usos de la Misma. IMPI No. Solicitud MX/a/2017/016444, 2017.

34. Seko, H.; Tsuge, K.; Igashira-Kamiyama, A.; Kawamoto, T.; Konno, T. Autoxidation of thiol-containing amino acid to its disulfide derivative that links two copper(II) centers: The important role of auxiliary ligand. Chem. Commun. 2010, 46, 1962-1964. [CrossRef]

35. Ugone, V.; Pisanu, F.; Sanna, D.; Garribba, E. Interaction of the potent antitumoral compounds Casiopeinas ${ }^{\circledR}$ with blood serum and cellular bioligands. J. Inorg. Biochem. 2021, 224, 111566-111576. [CrossRef]

36. Rivillas-Acevedo, L.; Grande-Aztatzi, R.; Lomelí, I.; García, J.E.; Barrios, E.; Teloxa, S.; Vela, A.; Quintanar, L. Spectroscopic and Electronic Structure Studies of Copper(II) Binding to His111 in the Human Prion Protein Fragment 106-115: Evaluating the Role of Protons and Methionine Residues. Inorg. Chem. 2011, 50, 1956-1972. [CrossRef] [PubMed]

37. Ames, W.M.; Larsen, S.C. DFT calculations of the EPR parameters for Cu(II) DETA imidazole complexes. Phys. Chem. Chem. Phys. 2009, 11, 8266-8274. [CrossRef]

38. Parker, S.F. Assignment of the vibrational spectrum of L-cysteine. Chem. Phys. 2013, 424, 75-79. [CrossRef]

39. Gaillard, T.; Trivella, A.; Stote, R.H.; Hellwig, P. Far infrared spectra of solid state L-serine, L-threonine, L-cysteine, and Lmethionine in different protonation states. Spectrochim. Acta-Part A Mol. Biomol. Spectrosc. 2015, 150, 301-307. [CrossRef] [PubMed]

40. Sekimoto, K.; Sakakura, M.; Kawamukai, T.; Hike, H.; Shiota, T.; Usui, F.; Bando, Y.; Takayama, M. Ionization characteristics of amino acids in direct analysis in real time mass spectrometry. Analyst 2014, 139, 2589-2599. [CrossRef] [PubMed]

41. Zhang, P.; Chan, W.; Ang, I.L.; Wei, R.; Lam, M.M.T.; Lei, K.M.K.; Poon, T.C.W. Revisiting Fragmentation Reactions of Protonated $\alpha$-Amino Acids by High-Resolution Electrospray Ionization Tandem Mass Spectrometry with Collision-Induced Dissociation. Sci. Rep. 2019, 9, 6453. [CrossRef] [PubMed]

42. Zhang, P.; Chan, W.; Ang, I.L.; Wei, R.; Lam, M.M.T.; Lei, K.M.K.; Poon, T.C.W. Gas-Phase Fragmentation Reactions of Protonated Cystine using High-Resolution Tandem Mass Spectrometry. Molecules 2019, 24, 747. [CrossRef]

43. Nicolescu, T.O. Interpretation of Mass Spectra. In Mass Spectrometry; Aliofkhazraei, M., Ed.; In Tech Open: Rijeka, Croatia, 2017; pp. $30-40$. 
44. Gutiérrez-Arzaluz, L.; Ramírez-Palma, D.I.; Ramírez-Palma, L.G.; Barquera-Lozada, J.E.; Peon, J.; Cortés-Guzmán, F. Origin of the Photoinduced Geometrical Change of Copper(I) Complexes from the Quantum Chemical Topology View. Chem.-Eur. J. 2019, 25, 775-784. [CrossRef]

45. Ramirez-Palma, D.I.; Cortes-Guzman, F. From Linnett-Gillespie Model to the Polarization of the Spin Valence Shells of Metals in Complexes. Phys. Chem. Chem. Phys. 2020, 22, 24201-24212. [CrossRef]

46. Stoll, S.; Schweiger, A. EasySpin, a comprehensive software package for spectral simulation and analysis in EPR. J. Magn. Reson. 2006, 178, 42-55. [CrossRef] [PubMed]

47. Frisch, M.J.; Trucks, G.W.; Schlegel, H.B.; Scuseria, G.E.; Robb, M.A.; Cheeseman, J.R.; Scalmani, G.; Barone, V.; Mennucci, B.; Petersson, G.A.; et al. Gaussian 09 (Revision E.01); Gaussian Inc.: Wallingford, CT, USA, 2009.

48. Bader, R. Atoms in Molecules. A Quantum Theory, 1st ed.; Oxford University Press: New York, NY, USA, 1990.

49. Keith, T.A. AIMAll (Version 16.01.09), TK Gristmill Software, Overland Park, KS, USA, 2016. Available online: aim.tkgristmill.com (accessed on 23 June 2021).

50. Neese, F. The ORCA program system. Wiley Interdiscip. Rev. Comput. Mol. Sci. 2012, 2, 73-78. [CrossRef]

51. García-Ramos, J.C.; Tovar-Tovar, A.; Hernández-Lima, J.; Cortés-Guzmán, F.; Moreno-Esparza, R.; Ruiz-Azuara, L. A new kind of intermolecular stacking interaction between copper (II) mixed chelate complex (Casiopeína III-ia) and adenine. Polyhedron 2011, 30, 2697-2703. [CrossRef] 